Ahmed A Al-Ali

BDS, MSc (Lec)

\section{The Effect of Different Denture Cleansers on Different Color Properties of Permanent Soft Liner}

\author{
Department of Prosthetic Dentistry \\ College of Dentistry, University of Mosul
}

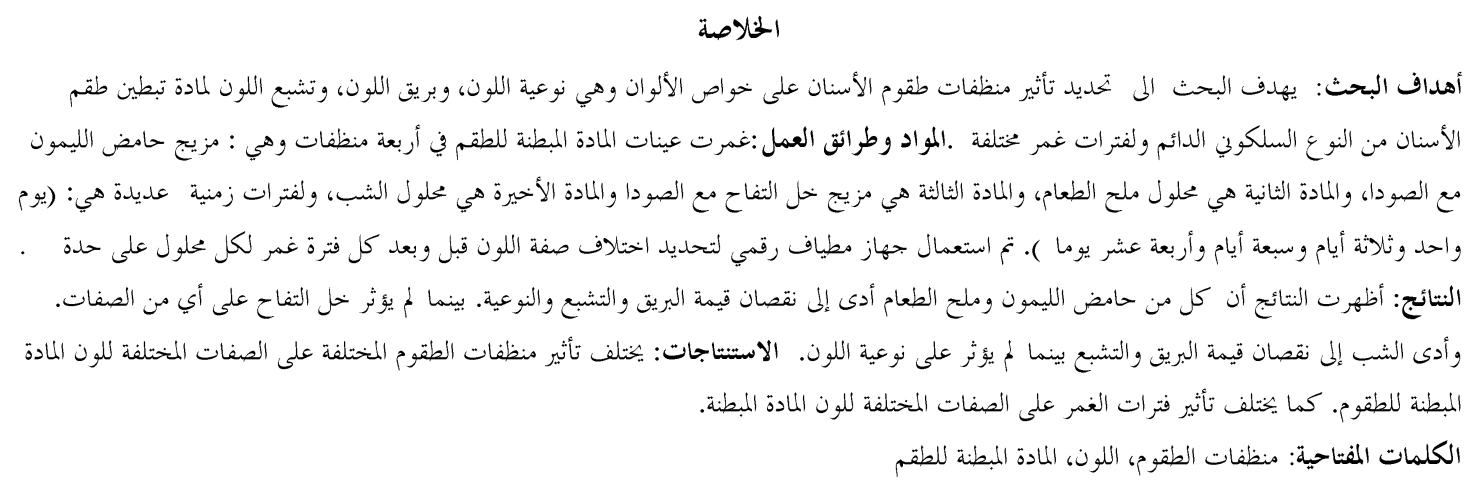

\title{
ABSTRACT
}

AIMS: To determine the effect of different denture cleansers on hue, value, and chroma of permanent silicone soft liner at different immersion periods. MATERIALS AND METHODS: Soft liner specimens were immersed in four denture cleansers ("citric acid + soda", salt, "apple vinegar + soda", and alum) for periods of $1,3,7$, and 14 days. A digital spectrophotometer was used to access color differences of soft liner before and after each storage period in each solution. RESULTS: The citric acid and salt cleansers decrease the value, chroma, and hue. The apple vinegar cleanser does not affect significantly any color property. The alum cleanser decrease value and chroma, but does not affect hue of soft liner. CONCLUSIONS: The effects of different denture cleansers tested on different color properties of soft liner were different. The effect of the immersion period on the different color properties tested was different for each denture cleanser.

Key Words: denture cleanser, color, soft liner.

Al-Ali AA. The Effect of Different Denture Cleansers on Different Color Properties of Permanent Soft Liner. Al-Rafidain Dent J. 2011; 11(1):78-87.

Received: 16/7/2009 Sent to Referees: $16 / 7 / 2009$

Accepted for Publication: 27/10/2009

\section{INTRODUCTION}

The use of soft denture liners has become increasingly popular for providing comfort for denture wearers. Soft denture liners are often used for patients who cannot tolerate a conventional denture base. ${ }^{(1)}$

The denture cleanliness is an essential component of oral health to prevent malodor, poor esthetic and accumulation of plaque and calculus with its deleterious effect on oral mucosal tissue. ${ }^{(2)}$

A chemical soaking technique is primarily the method of choice for geriatric patients and for those with poor motor capacity. ${ }^{(3,4)}$

Denture cleaners can cause significant deterioration of soft liners because they can cause loss of soluble components and plasticizers, or absorption of water or saliva by the soft liners. Thus the selection of denture cleanser should be considered to avoid or minimize changes in the properties of soft liners. ${ }^{(3,4)}$

There is some knowledge about the changes in color stability of soft denture lining materials caused by denture cleansers. ${ }^{(5,6)}$

Many researchers attempt to use natural, locally available materials as denture cleansers. Of the important materials used are citric acid, sodium chloride, vinegar, and alum. ${ }^{(2,7-9)}$

The color stability criteria may provide an important information on the serviceability of the dental materials. ${ }^{(10)}$

Color is a three-dimensional phenomenon. The three dimensions are hue, value, and chroma. Hue is the quality that 
distinguishes one family of colors from another. It is specified as the dominant range of wavelengths in the visible spectrum that yields the perceived color, even though the exact wavelength of the perceived color may not be present because in fact hue is an interpretation of a sum of wavelengths. Value, or brightness, is the amount of light returned from an object. Munsell described value as a white toblack gray scale. Bright objects have lower amounts of gray, and low-value objects have larger amounts of gray and will appear darker. Lowering value means diminished light returns from the object illuminated; more light is being absorbed, scattered elsewhere, or transmitted through. Chroma is the saturation, intensity, or strength of the color. ${ }^{(11)}$

The aim of this research is to determine the effect of four denture cleansers (which are "citric acid + soda", salt, "apple vinegar + soda", and alum) on the three dimensions of color (which are hue, value, and chroma) of permanent silicone soft liner at different immersion periods.

\section{MATERIALS AND METHODS}

Permanently soft polyvinyl siloxane reline material (Mucopren soft, Germany) was processed following the manufacturers instructions to produce circular specimens with a diameter of $30 \mathrm{~mm}$ and a thickness of $1 \mathrm{~mm} .^{(3)}$

Four natural, locally available denture cleansers were used ${ }^{(2)}$ :
1- Citric acid $(4.57 \mathrm{~g})+$ soda(sodium bicarbonate $)(2 \mathrm{~g})+$ water $(100 \mathrm{ml})$.

2- Salt $(40 \mathrm{~g})+$ water $(100 \mathrm{ml})$.

3 -Apple vinegar(acetic acid) (5ml)+soda $(7 \mathrm{~g})+$ water $(100 \mathrm{ml})$.

4- $\operatorname{Alum}(5 \mathrm{~g})+$ water(100ml).

For each denture cleanser, ten specimens were prepared to be evaluated.

The specimens were immersed in distilled water for 7 days for conditioning. During the storage of specimens in water and subsequently during their immersion in the denture cleansers, the specimens were suspended in the solutions by a stainless steel dental wire passing through the center. This will hold the specimens in a vertical position and prevent the contact between the specimens during their immersion in the tested solutions, so each specimen was in contact only with the immersing solutions. ${ }^{(10,2)}$

After the specimens were taken out, initial color measurements were taken. ${ }^{(12)}$

A digital spectrophotometer (Easyshade, Vita, Germany) was used to measure the color properties of soft liner specimens including the value, chroma, and hue which displayed digitally on the device (Figure 1). Easyshade spectrophotometer contain a color analyzer with its own light source that has accompanying software for the downloading, evaluation, and transmission of the relevant color data recorded. It standardize the measurements of hue, value, and chroma.

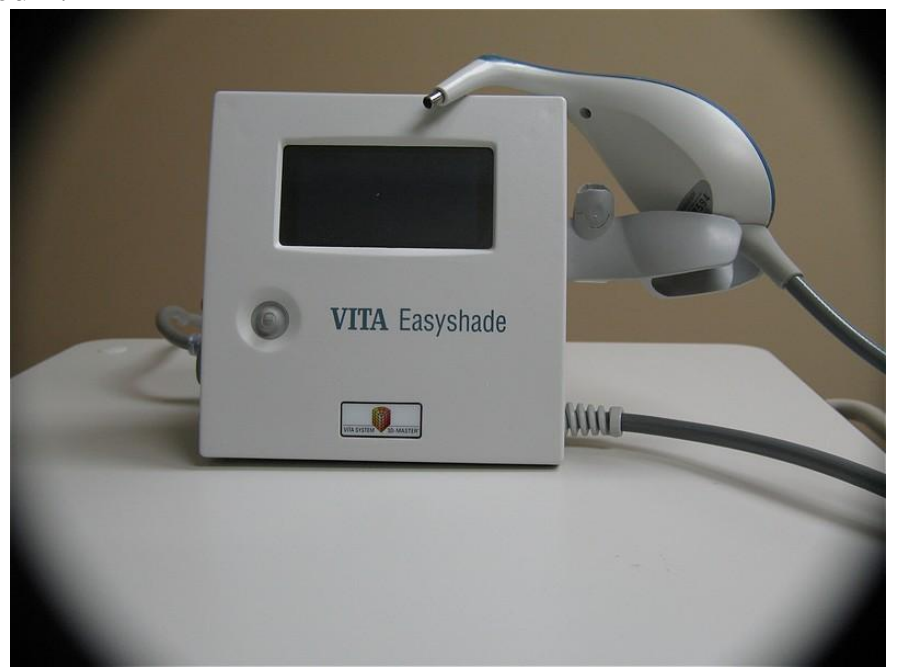

Figure(1):The Vita Easyshade digital spectrophotometer 
The color distribution of Easyshade was more ordered (in the value, chroma, and hue scale) than previously reported color distributions of other, traditional shade guides. ${ }^{(13)}$

The Easyshade spectrophotometer was the most reliable instrument in both in vitro and in vivo circumstances. ${ }^{(14)}$

The individual white color index of the instrument was used as a color control. ${ }^{(12,15)}$

The specimens were immersed in denture cleanser solutions for $1,3,7$, and 14 days. $^{(16)}$

Specimens placed in water served as controls. Color differences before and after each storage period in each solution were assessed. ${ }^{(16,12)}$

Mean values for the effect of type of denture cleanser on three properties of the color tested at each immersion period were compared using ANOVA followed by
Duncan multiple range test to determine the significant difference at $\mathrm{P}<0.05$ level.

\section{RESULTS}

The effect of the immersion period on the different color properties tested was different for each denture cleanser.

At the first day, the effects of different denture cleansers on the value of permanent soft liner were significant $(\mathrm{P}=0.000)($ Table 1$)$; with the citric acid cleanser significantly decrease value, and the effects of other cleansers are shown on(Figure 2).The effects on chroma were also significant $(\mathrm{P}=0.000)$ (Table 1$)$; with the salt and alum cleansers significantly decrease chroma, while the citric acid and vinegar cleansers do not (Figure 3).The effects on hue were not significant when compared with the control group(Table 1, Figure 4).

Table(1):ANOVA test of denture cleansers and control at the first day

\begin{tabular}{|c|c|c|c|c|c|c|}
\hline & & Sum of Squares & df & Mean Square & $\mathbf{F}$ & Sig. \\
\hline \multirow{3}{*}{ Value } & Between Groups & 122.443 & 4 & 30.611 & 6.210 & 0.000 \\
\hline & Within Groups & 221.816 & 45 & 4.929 & & \\
\hline & Total & 344.259 & 49 & & & \\
\hline \multirow{3}{*}{ Chroma } & Between Groups & 7.757 & 4 & 1.939 & 9.273 & 0.000 \\
\hline & Within Groups & 9.411 & 45 & 0.209 & & \\
\hline & Total & 17.168 & 49 & & & \\
\hline \multirow{3}{*}{ Hue } & Between Groups & 93.105 & 4 & 23.276 & 1.491 & 0.221 \\
\hline & Within Groups & 702.411 & 45 & 15.609 & & \\
\hline & Total & 795.516 & 49 & & & \\
\hline
\end{tabular}

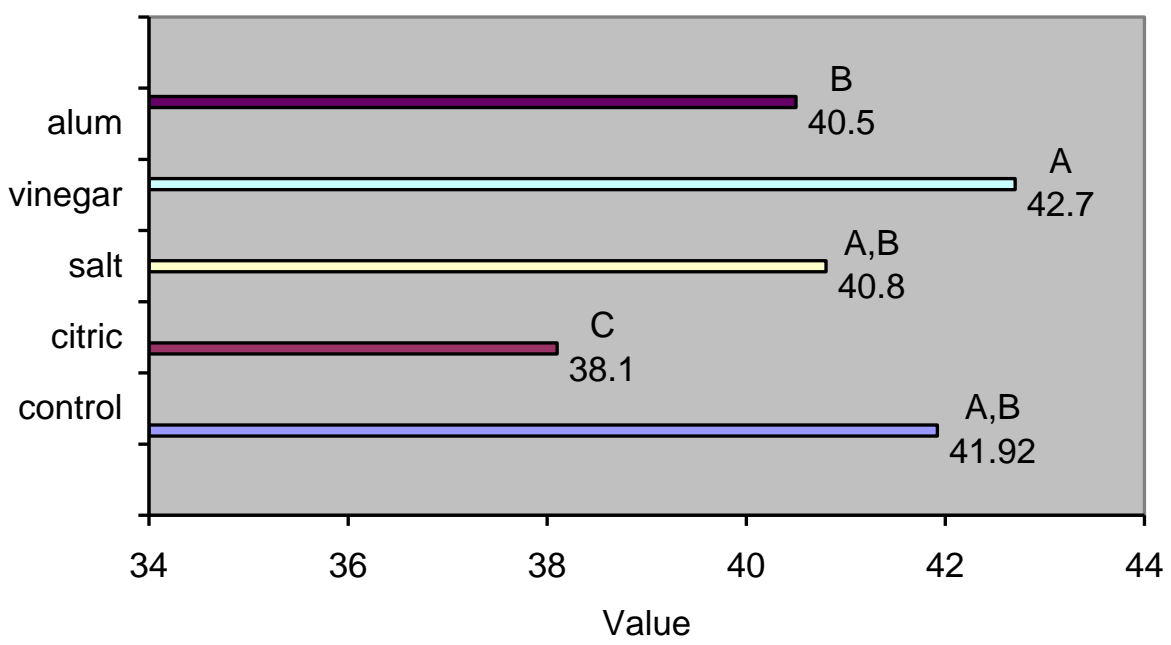

Figure(2):Duncan Multiple Rang Test for value at the first day 


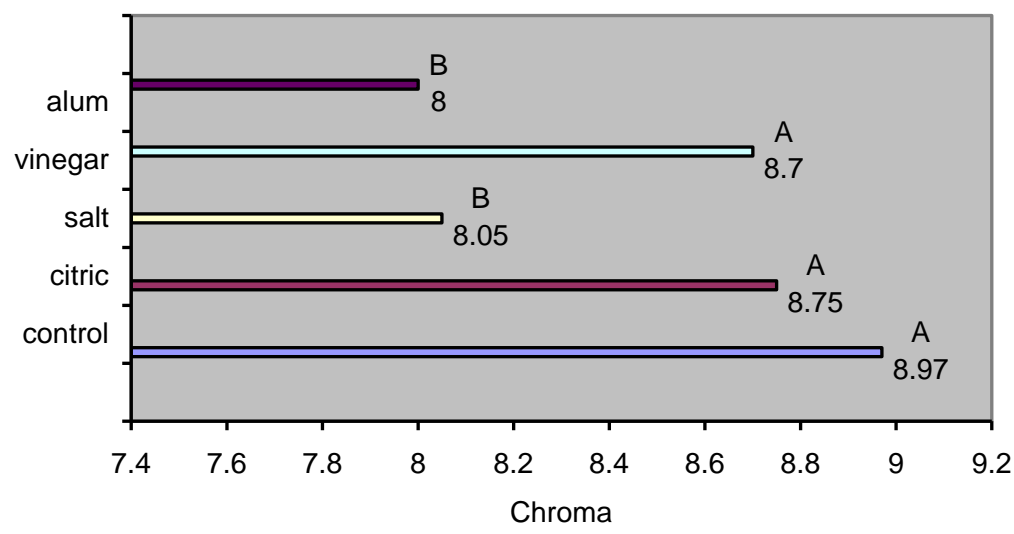

Figure(3):Duncan Multiple Rang Test for Chroma at the first day

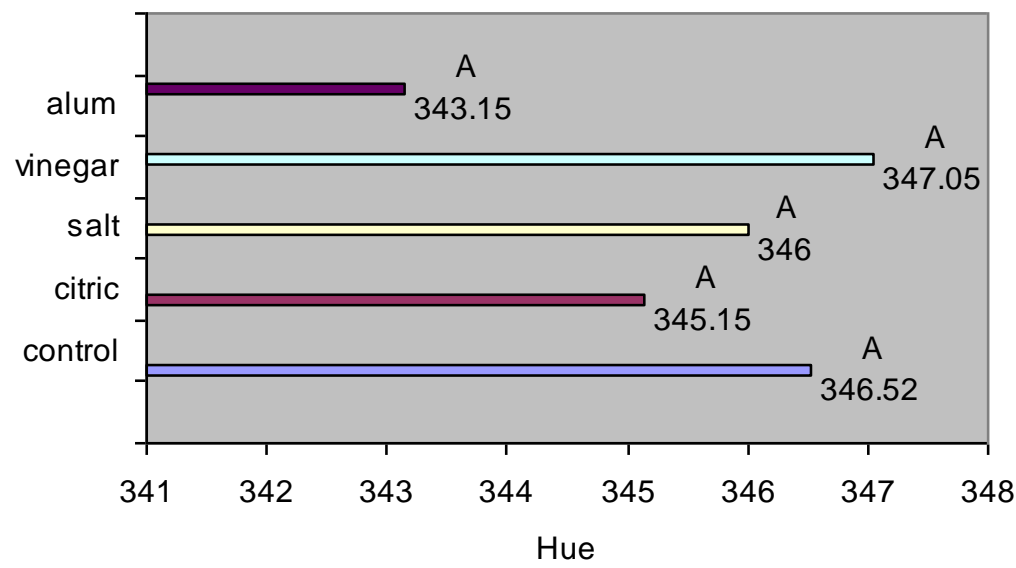

Figure(4):Duncan Multiple Rang Test for Hue at the first day

At the third day, the effects of denture cleansers on value were significant $(\mathrm{P}=0.008)$ (Table 2); with the citric acid, salt, and alum cleansers significantly decrease value; the results are more illustrated in(Figure 5). The effects on chroma were significant $(\mathrm{P}=0.002)($ Table 2$)$; with the citric acid, salt, and alum cleansers significantly decrease chroma while vinegar cleanser does not(Figure 6). The effects on hue were significant $(\mathrm{P}=0.002)$ (Table 2); with the citric acid and salt cleansers significantly decrease hue while the vinegar and alum cleansers do not(Figure7).

Table(2):ANOVA test of denture cleansers and control at the third day

\begin{tabular}{|c|c|c|c|c|c|c|}
\hline & & Sum of Squares & df & Mean Square & F & Sig. \\
\hline \multirow{3}{*}{ Value } & Between Groups & 47.125 & 4 & 11.781 & 3.975 & 0.008 \\
\cline { 2 - 8 } & Within Groups & 133.373 & 45 & 2.964 & & \\
\cline { 2 - 8 } Chroma & Total & 180.498 & 49 & & & \\
\hline \multirow{3}{*}{ Hue } & Between Groups & 8.659 & 4 & 2.165 & 5.141 & 0.002 \\
\cline { 2 - 8 } & Within Groups & 18.948 & 45 & 0.421 & & \\
\cline { 2 - 8 } & Total & 27.607 & 49 & & & \\
\hline & Between Groups & 650.988 & 4 & 162.747 & 5.095 & 0.002 \\
\cline { 2 - 8 } & Within Groups & 1437.397 & 45 & 31.942 & & \\
\cline { 2 - 8 } & Total & 2088.385 & 49 & & & \\
\hline
\end{tabular}




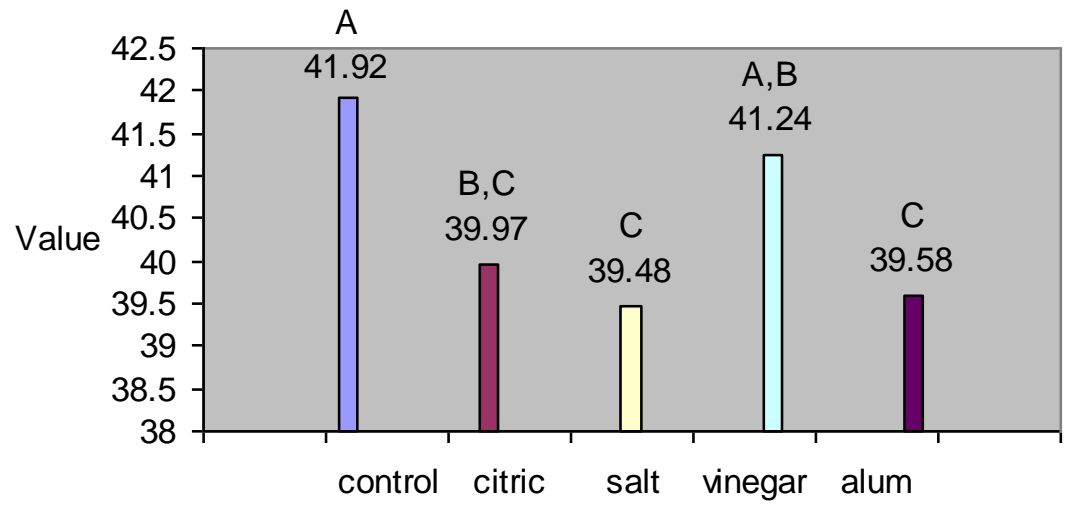

Figure(5):Duncan Multiple Rang Test for value at the third day

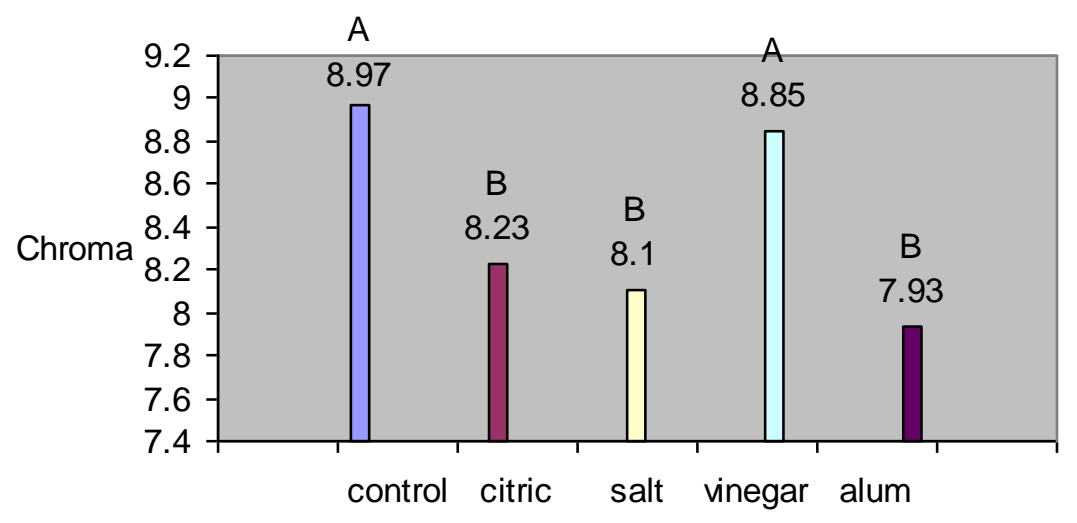

Figure(6):Duncan Multiple Rang Test for Chroma at the third day

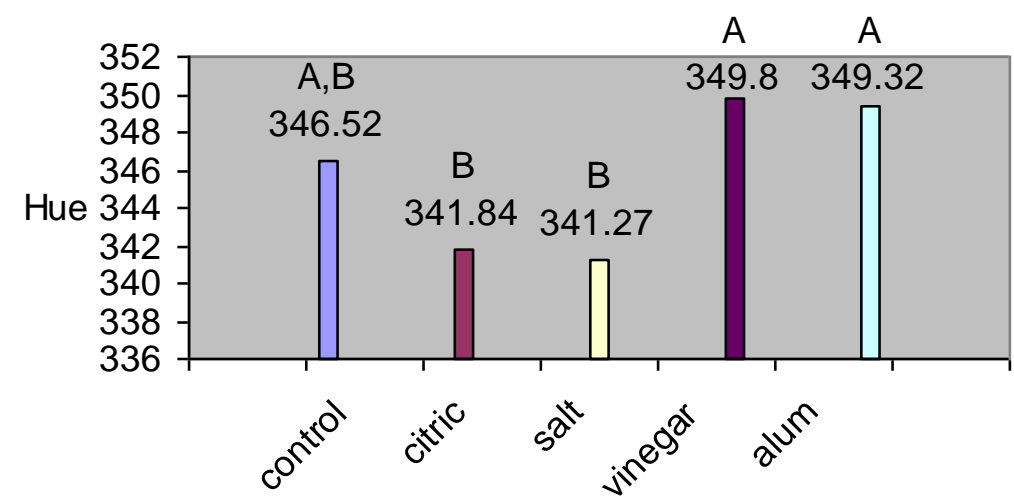

Figure(7):Duncan Multiple Rang Test for Hue at the third day

At the seventh day, the effects on value were significant $(\mathrm{P}=0.010)($ Table 3$)$; with the citric acid, salt, and alum cleansers significantly decrease value. The results are more specified in(Figure 8). The effects on chroma were significant $(\mathrm{P}=0.000)$ (Table 3); with the citric acid, salt, and alum cleansers significantly decrease chroma while the vinegar cleanser does not(Figure 9). The effects on hue were significant $(\mathrm{P}=0.041)($ Table 3$)$; with the citric acid cleanser decrease hue and the other results are shown on(Figure 10). 
Table(3):ANOVA test of denture cleansers and control at the seventh day

\begin{tabular}{|c|c|c|c|c|c|c|}
\hline & & Sum of Squares & df & Mean Square & F & Sig. \\
\hline \multirow{3}{*}{ Value } & Between Groups & 46.265 & 4 & 11.566 & 3.739 & 0.010 \\
\cline { 2 - 8 } & Within Groups & 139.214 & 45 & 3.094 & & \\
\cline { 2 - 8 } Chroma & Total & 185.479 & 49 & & & \\
\hline \multirow{3}{*}{ Hue } & Between Groups & 10.897 & 4 & 2.724 & 6.425 & 0.000 \\
\cline { 2 - 8 } & Within Groups & 19.080 & 45 & 0.424 & & \\
\cline { 2 - 8 } & Total & 29.977 & 49 & & & \\
\cline { 2 - 8 } & Between Groups & 422.029 & 4 & 105.507 & 2.726 & 0.041 \\
\cline { 2 - 8 } & Within Groups & 1741.754 & 45 & 38.706 & & \\
\hline & Total & 2163.783 & 49 & & & \\
\hline
\end{tabular}

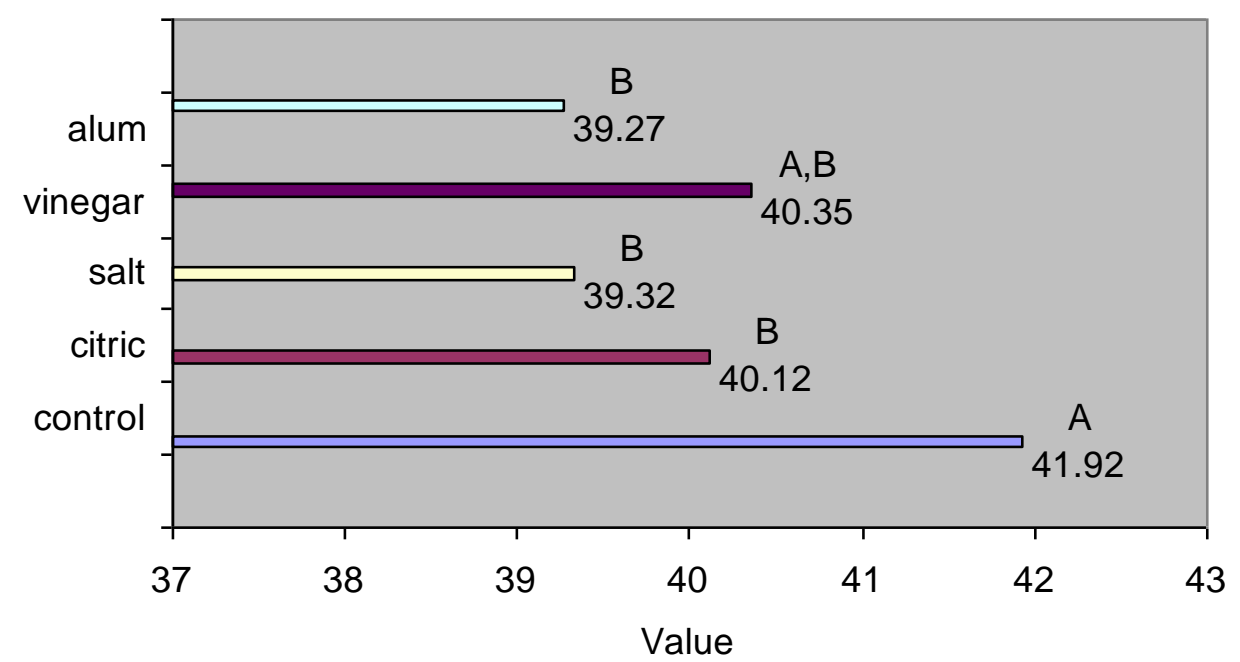

Figure(8):Duncan Multiple Rang Test for value at the seventh day

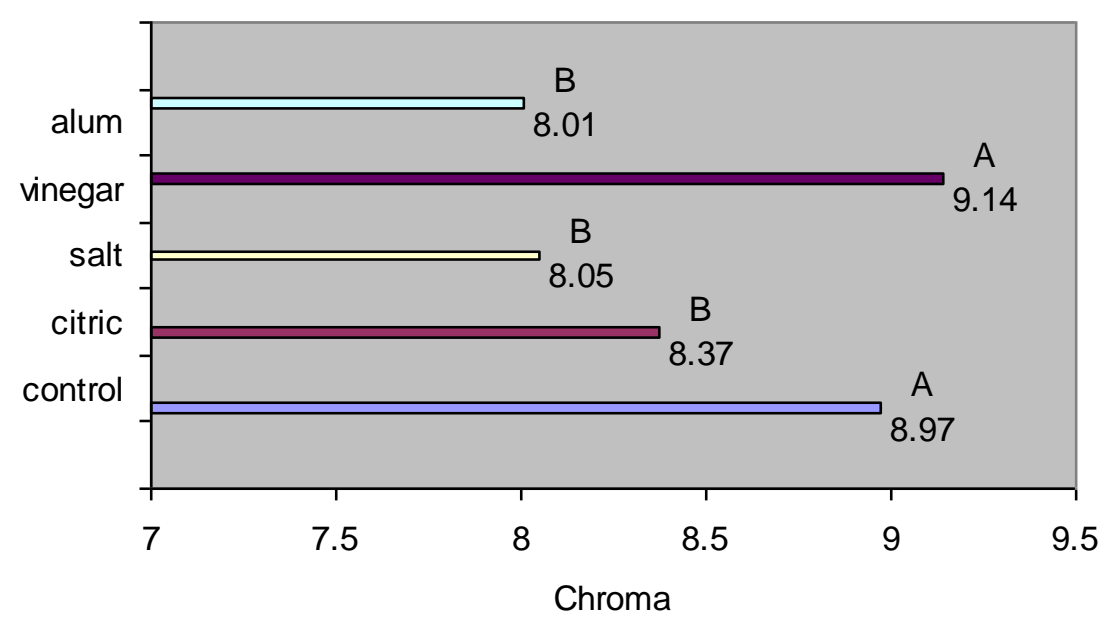

Figure(9):Duncan Multiple Rang Test for Chroma at the seventh day 


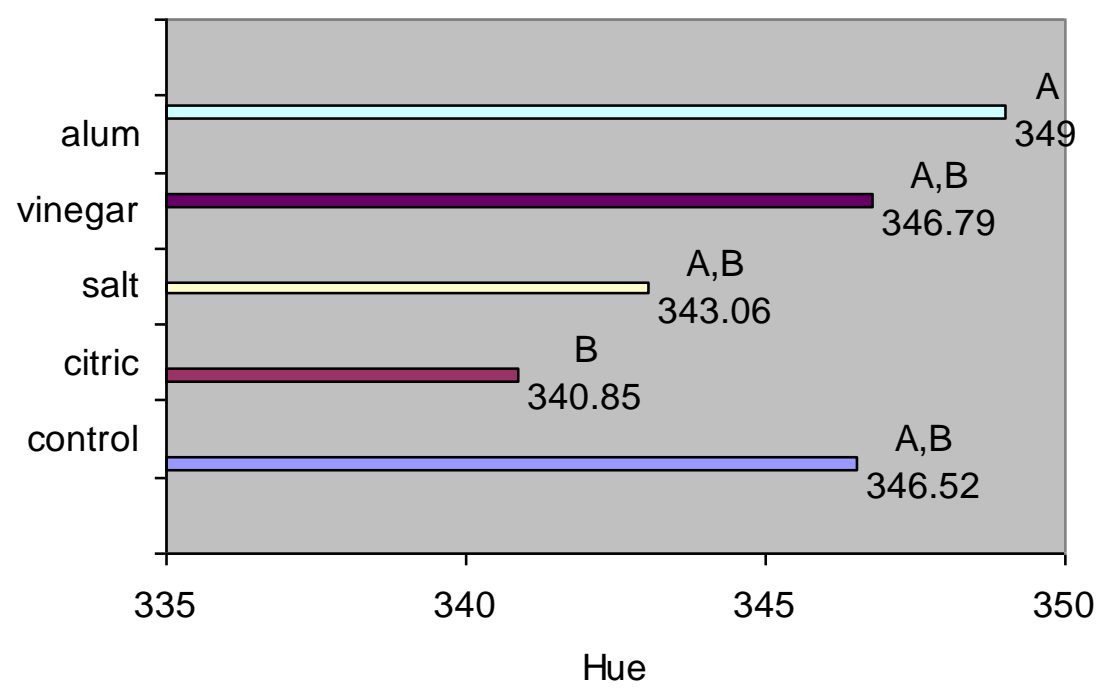

Figure(10):Duncan Multiple Rang Test for Hue at the seventh day

At the fourteenth day, the effects on value were significant $(\mathrm{P}=0.000)$ (Table 4$)$; with the citric acid, salt, and alum cleansers significantly decrease value and the vinegar cleanser does not(Figure 11). The effects on chroma were significant $(\mathrm{P}=0.000)($ Table 4$)$; with the citric acid, salt, and alum cleansers significantly decrease chroma while the vinegar cleanser does not (Figure 12). The effect on hue were significant $(\mathrm{P}=0.001)$ (Table 4$)$; with the citric acid and salt cleansers significantly decrease hue while the vinegar and alum cleansers do not(Figure 13).

Table(4):ANOVA test of denture cleansers and control at the fourteenth day

\begin{tabular}{|c|c|c|c|c|c|c|}
\hline & & Sum of Squares & df & Mean Square & F & Sig. \\
\hline \multirow{4}{*}{ Value } & Between Groups & 82.305 & 4 & 20.576 & 8.961 & 0.000 \\
\cline { 2 - 8 } & Within Groups & 103.330 & 45 & 2.296 & & \\
\cline { 2 - 8 } Chroma & Total & 185.635 & 49 & & & \\
\hline \multirow{3}{*}{ Hue } & Between Groups & 9.687 & 4 & 2.422 & 6.378 & 0.000 \\
\cline { 2 - 8 } & Within Groups & 17.087 & 45 & 0.380 & & \\
\cline { 2 - 8 } & Total & 26.774 & 49 & & & \\
\hline & Between Groups & 773.761 & 4 & 193.440 & 5.406 & 0.001 \\
\hline & Within Groups & 1610.342 & 45 & 35.785 & & \\
\cline { 2 - 8 } & Total & 2384.103 & 49 & & & \\
\hline
\end{tabular}

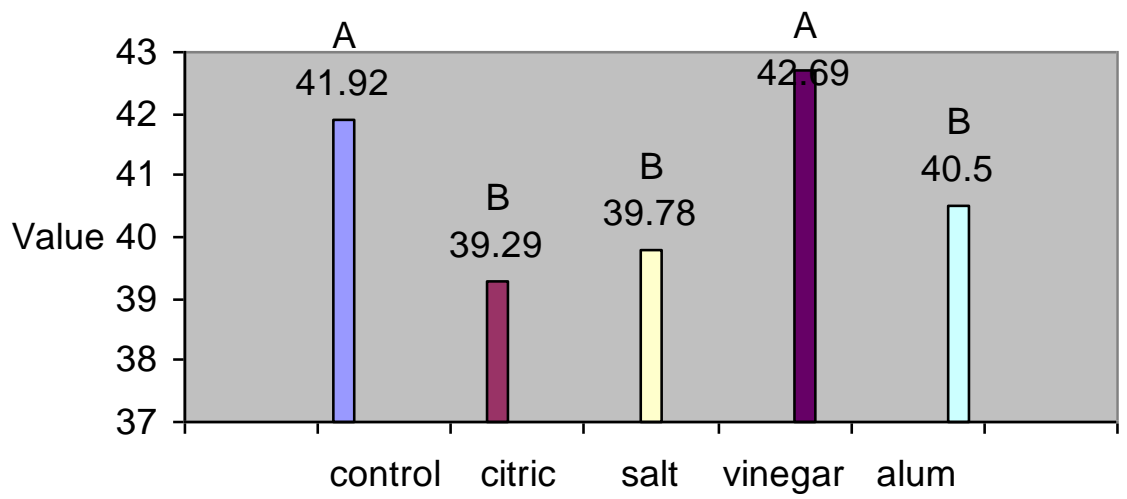

Figure(11):Duncan Multiple Rang Test for value at the fourteenth day 


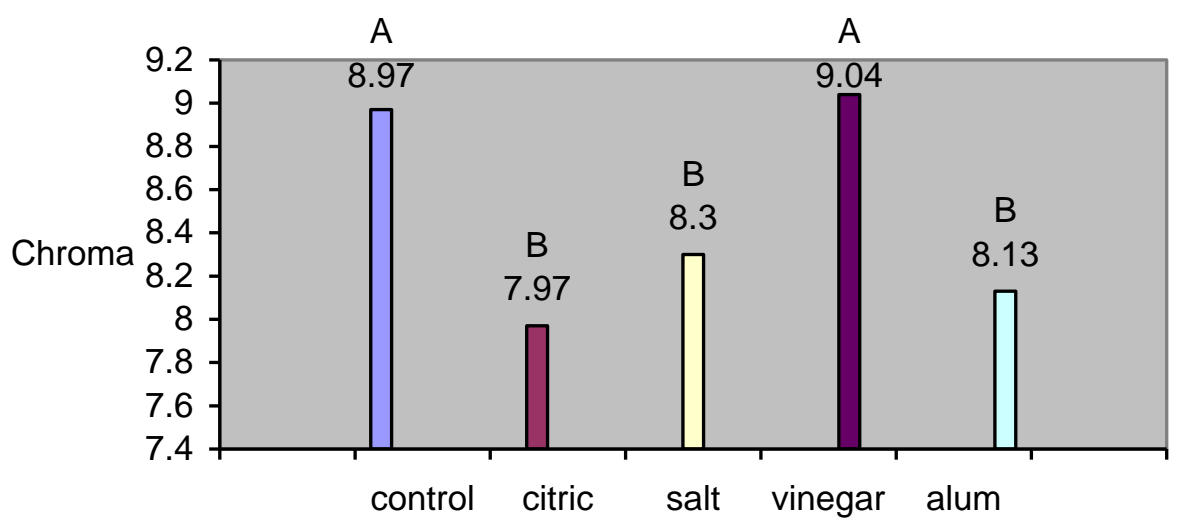

Figure(12):Duncan Multiple Rang Test for Chroma at the fourteenth day

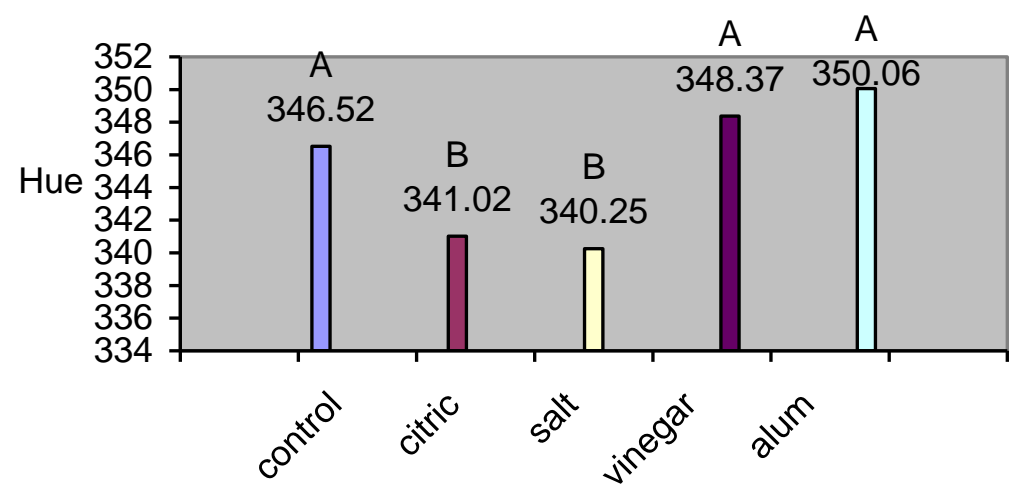

Figure(13):Duncan Multiple Rang Test for Hue at the fourteenth day

\section{DISCUSSION}

It has been reported that denture cleansers can cause loss of soluble components and plasticizers, or absorption of water or saliva by the soft lining materials. ${ }^{(17)}$

The mechanism of color change cannot be known exactly, but it can be estimated. ${ }^{(18)}$

The color change of the denture base polymer may be also caused by penetration of the colored substance through the process of sorption. Therefore, if the contacting solutions are pigmented, discoloration will be possible. ${ }^{(10)}$

The color changes of soft denture liners are attributed to changes in the colorants used, a change in color of the elastomer, or both. Some colorants or elastomers may be affected by high humidity. ${ }^{(19)}$

"Citric acid+ soda" produced a significant decrease in the value, chroma, and hue of the soft liner specimens and this decrease may be due to the chelating property of the sodium citrate that is produced from the reaction between the citric acid and soda(sodium bicarbonate). This can be illustrated as sodium citrate solution has $\mathrm{pH}$ value close to the neutral which makes it more effective in chelation (removal of the organic and inorganic components of the deposit). The chelating process will involve removal of colorant substances of material. ${ }^{(20,8)}$ These findings are in agreement with $\mathrm{Al}-$ Aubadi. ${ }^{(2)}$

"Apple vinegar+ soda"(Acidic denture cleanser) was shown to affect insignificantly the value, chroma, and hue of the soft liner specimens. These findings are in agreement with Al-Abbas and Asmussen who found that the reduction of the $\mathrm{pH}$ of the storage water had only little effect on the color of acrylic resin materials..$^{(10,21)}$

Alum (potassium Aluminum sulphate) produced a significant decrease in the value and chroma of the soft liner specimens. This may be due to the fact that when the non-aqueous solution of the 
aluminum salt dissolved in the water the eighth surfaces aluminum ion formed [AL $\left.\left(\mathrm{H}_{2} \mathrm{O}\right)_{6}\right]^{+3}$. It will then hydrolyze to form $\left(\mathrm{H}_{3} \mathrm{O}\right)^{+}$that gives acidity to the solution.

$$
2 \mathrm{KAL}\left(\mathrm{SO}_{4}\right) 2+12 \mathrm{H}_{2} \mathrm{O} \rightarrow 2[\mathrm{AL}
$$
$\left.\left(\mathrm{H}_{2} \mathrm{O}\right)_{6}\right]^{+3}+\mathrm{K}_{2} \mathrm{SO}_{4}$

The very high acidity of the solution $(\mathrm{pH}=3.27)$ leads to an increase in water sorption. ${ }^{(2)}$

\section{CONCLUSIONS}

The effects of different denture cleansers tested on different color properties of permanent soft liner tested were different. The effect of the immersion period on the different color properties tested was different for each denture cleanser. The citric acid solution cleanser decrease value, chroma, and hue. The salt solution cleanser decrease value, chroma, and hue. The citric acid and salt solution cleansers differ in their effect in relation to the amount of decrease in all color properties tested and the time required for such change. The apple vinegar solution cleanser does not affect significantly any of the color properties tested. The alum solution cleanser decrease value and chroma, but does not affect hue.

\section{REFERENCES}

1. Anusavice K. Phillips' Science of Dental Materials (ed 11). Philadelphia, Saunders, 2003, pp. 269-271.

2. Al-Aubadi S. New Denture Cleansers, A Comparative Study. 2007. M.Sc. Thesis, Mosul University, College of Dentistry.

3. Garcia R, Leon B, Oliveira V, Cury A. Effect of a denture cleanser on weight, surface roughness, and tensile bond strength of two resilient denture liners. $J$ Prosthet Dent .2003;89:489-94.

4. Nikawa H, Iwanaga $H$, Hamada $T$, Yuhta S. Effects of denture cleansers on direct soft denture lining materials. J Prosthet Dent .1994;72:657-62.

5. Qudah S, Harrison A, Huggett R. Soft lining materials in prosthetic dentistry: a review. Int J Prosthodont .1990;3:477483.

6. Tan H, Woo A, Kim S, Lamoureux M, Grace M. Effect of denture cleansers, surface finish, and temperature on Molloplast $\mathrm{B}$ resilient liner color, hardness, and texture. J Prosthodont. 2000;9:148-155.
7. Sousa S, Bramante C, Taga E. Biocompatibility of EDTA, EGTA and citric acid. Braz Dent J. 2005; 16: 3-8.

8. Machado-Silveiro L, Gonzales-Lopez S, Gonzales U, Rodriguez M. Decalcification of root canal dentine by citric acid, EDTA and sodium citrate. Int Endodon J. 2004; 37: 365-369.

9. Basson N, Quick A, Thomas C. Household products as sanitizing agents in denture cleansing. $J$ Dent Assoc $S$ Africa.1992; 47:437.

10. Al-Abbas Z. Evaluation of the Effect of Some Denture Cleansers on the Colour of Acrylic Resin Denture Base Materials. 2002. M.Sc. Thesis, Mosul University, College of Dentistry.

11. Fondriest J. Shade Matching in Restorative Dentistry: The Science and Strategies. Int J Periodont \& Restorat Dent. 2003;23:3-15.

12. Sarac D, Sarac Y, Kurt M, Yuzbasioglu E. The Effectiveness of Denture Cleansers on Soft Denture Liners Colored by Food Colorant Solutions. J Prosthodont 2007;16:185-191.

13. Jin-Soo A, Yong-Keun L. Color distribution of a shade guide in the value, chroma, and hue scale. $J$ Prosthet Dent. 2008;100:18-28.

14. Dozic A, Kleverlaan C, El-Zohairy A, Feilzer A, Khashayar G. Performance of Five Commercially Available Tooth Color-Measuring Devices. J Prosthodont .2007; 16:93-100.

15. Anil N, Hekimoglu C, Sahin S. Color stability of heat-polymerized and autopolymerized soft denture liners. $J$ Prosthet Dent .1999;81:481-4.

16. Lai $\mathrm{Y}$, Lui $\mathrm{H}$, Lee $\mathrm{S}$. In vitro color stability, stain resistance, and water sorption of four removable gingival flange materials. J Prosthet Dent .2003;90:293300.

17. Jones D, Hall G, Sutow E. Chemical and molecular weight analyses of prosthodontic soft polymers. $J$ Dent Res .1991;70:874-879.

18. Dootz E, Koran A, Craig R. Physical property comparison of 11 soft denture lining materials as a function of accelerated aging. J Prosthet Dent .1993; 69:114-9. 
19. Shotwell J, Razzoog M, Koran A. Color stability of long-term soft denture liners. J Prosthet Dent .1992;68:836-8.

20. Lenarda R, Cadenaro M, Sbaizero O. Effectiveness of $1 \mathrm{~mol} / \mathrm{L}$ Citric acid and
$15 \%$ EDTA irrigation on smear layer removal. Int Endodont J. 2000; 33:46-52.

21. Asmussen E. Factors affecting the color stability of restorative resin. Acta Odontol Scand.1983; 41:11-18. 